\title{
STRATEGIE I TECHNIKI FORMUŁOWANIA UZASADNIEŃ ORZECZEŃ SĄDOWYCH
}

\section{WPROWADZENIE}

Uzasadnienie orzeczenia sądowego jest szczególnym rodzajem wypowiedzi. Stanowi wypadkowa realizacji obowiązku proceduralnego nałożonego na sąd z jednej strony, z drugiej zaś - społecznie i kulturowo uwarunkowanej potrzeby wskazania motywów decyzji o charakterze władczym podejmowanych wobec innych podmiotów ${ }^{1}$. W związku z tym sposób uregulowania jego sporządzenia przez sąd łączy w sobie cechy „formalne” oraz elementy kreujące po stronie autora uzasadnienia pewien zakres swobody. Podstawowe przepisy odnoszace się do budowy uzasadnienia regulują uzasadnienie wyroku i maja podobną konstrukcję we wszystkich procedurach sądowych. Wskazują na podstawowe elementy składowe uzasadnienia, z ewentualnym ogólnym dookreśleniem ich cech (jak w przypadku art. $141 \S 4$ p.p.s.a., zgodnie z którym uzasadnienie powinno zawierać „zwięzłe przedstawienie stanu sprawy") ${ }^{2}$. Szczegółowe wypełnienie treścią wskazanych w przepisach składników uzasadnienia pozostawione zostało w gestii autora uzasadnienia. Wobec tego praktyka sądowa wykształciła w tym zakresie pewien uzus, nadal jednak niektóre bardziej szczegółowe kwestie pozostają indywidualną rola sporządzającego uzasadnienie. $Z$ powodu potrzeby zachowania elastyczności tego rodzaju wypowiedzi, zwłaszcza w związku z przypadkami niedającymi się przewidzieć oraz złożonością (wieloaspektowościa) zjawiska uzasadniania $^{3}$, nie jest możliwe uregulowanie - ani formalne, ani w drodze konsensu praktyki uzasadniania - konstrukcji uzasadnienia w sposób sztywny, ostateczny, jedynie właściwy i oderwany od jednostkowych preferencji formułowania wypowiedzi.

1 O różnicy uzasadniania przez sądy w państwie autokratycznym i demokratycznym zob. szerzej:. E. Łętowska et al., Podstawy uzasadniania w prawie konstytucyjnym i międzynarodowym, w: I. Rzucidło-Grochowska, M. Grochowski (red.), Uzasadnienia decyzji stosowania prawa, Warszawa 2015, s. 15-16.

2 Przepisy regulujące konstrukcję uzasadnienia to art. $141 \S 4$ p.p.s.a., art. 328 § 2 k.p.c. i art. 424 k.p.k.

${ }^{3}$ Zob. szerzej na temat złożoności zjawiska uzasadniania orzeczeń sądowych: I. Rzucidło, Wielowymiarowość uzasadnienia decyzji stosowania prawa, w: M. Zuralska (red.), Interdyscyplinarne ujęcie prawa. Materiaty ogólnopolskiej konferencji naukowej „Prawo i...” Zasadność interdyscyplinarnego ujęcia prawa, Warszawa 2-3 grudnia 2011 r., Warszawa 2013. 
Margines swobody oddany sędziemu jako autorowi uzasadnienia jest przez niego zagospodarowywany w różny sposób, w zależności od indywidualnych preferencji i kompetencji w zakresie uzasadniania orzeczeń. Może przejawiać się on w zorganizowaniu redakcyjnym czy edycyjnym treści uzasadnienia (np. stosowanie numeracji, śródtytułów itp. $)^{4}$ albo $\mathrm{w}$ sposobie ujęcia myśli w słowa i ramy retoryczne, konstruowania argumentacji. To ostatnie jest w istocie kwestią stosowania odpowiednich strategii i technik uzasadniania, wyróżnionych w ramach kategorii stylu uzasadniania, rozumianego na poziomie ogólnej właściwości uzasadnienia, nie zaś jako stylu wynikającego z cech danego porządku prawnego ${ }^{5}$. Ponieważ kwestia stylu uzasadniania jest zagadnieniem niezwykle bogatym i zasługuje na uwage wykraczająca poza ramy przewidziane dla artykułu naukowego, przedmiotem zainteresowania tego opracowania jest problematyka strategii i technik tworzenia pisemnych uzasadnień orzeczeń sądowych. Wnioski zaprezentowane poniżej są efektem szerokich badań orzecznictwa, przede wszystkim treści uzasadnień sądowych, a także literatury odnoszącej się do problematyki formułowania uzasadnienia. Punkt wyjścia stanowiła w przeważającej mierze analiza uzasadnień sądów administracyjnych, ale wynikajace $\mathrm{z}$ niej ustalenia mają charakter bardziej uniwersalny i rozciagają się co do zasady także na uzasadnienia innych sądów. Zaprezentowano przy tym najciekawsze i najistotniejsze zaobserwowane strategie i techniki uzasadniania, ze świadomościa, że w ramach poszczególnych postępowań występują również bardziej szczegółowe ich odmiany.

W uzasadnieniach sądowych w praktyce (przepisy prawa milczą na ten temat) wyodrębnia się zasadniczo ich dwa elementy konstrukcyjne: tzw. część historyczną i część prawna. Pierwsza obejmuje opis historii sprawy i - na tym tle - stanu faktycznego, druga natomiast rozważania o charakterze prawnym (w pewien sposób odzwierciedla czynności w ramach ustalenia stanu prawnego). Niekiedy wyróżnia się także część poświęconą przedstawieniu i ocenie dowodów - jako osobny element uzasadnienia albo składnik części historycznej lub prawnej. Wykorzystanie strategii i technik sporządzania uzasadnienia obserwuje się w odniesieniu do obu zasadniczych części uzasadnienia (z tym że bardziej naturalną przestrzenią dla stosowania technik jest raczej część prawna, dlatego że cechuje się ona większą swobodą co do jej zawartości niż część historyczna, która zdeterminowana jest wypowiedziami stron i innych podmiotów, okolicznościami sprawy itp.).

\footnotetext{
${ }^{4}$ Kwestia redakcyjnego zorganizowania treści uzasadnienia wykracza poza ramy tego opracowania i zasługuje na osobną uwagę.

${ }^{5}$ Kategoria stylu uzasadniania nie jest rozumiana jednolicie we wszystkich porządkach prawnych. Styl właściwy dla danego systemu prawnego jest osobną kategorią pojęciową, lokująca się na innym poziomie niż pozostałe sposoby postrzegania tego zjawiska. W takim rozumieniu jest on emanacją założeń stosowania prawa i samego postrzegania prawa. Wyróżnia się w tym ujęciu zasadniczo trzy podstawowe style formułowania uzasadnienia - francuski, niemiecki i anglo-amerykański. Zob. E. Łętowska, Pozaprocesowe znaczenie uzasadnienia squdowego, „Państwo i Prawo" 1997, z. 5, s. 3-5.
} 


\section{STRATEGIE UZASADNIANIA}

Jak wskazano wyżej, o sposobie prezentowania treści, jakie mają znaleźć się w uzasadnieniu, decydują strategie przyjmowane przez jego autora. Dotyczą one sposobu kreowania narracji prowadzonej w uzasadnieniu. Wiażą się z celami, jakie autor uzasadnienia chce osiagnać przez tę wypowiedź - które z kolei dyktowane są innymi kwestiami, zwłaszcza kręgiem jej adresatów. Uzasadnienie wydaje się w tym świetle gra z jego odbiorcami. Strategie sa wykorzystywane, jak powiedziano, przy tworzeniu obu części uzasadnienia. W każdej z nich problematyka ta kształtuje się jednak odmiennie. Warto zauważyć, że niektóre strategie wykluczają się wzajemnie, inne zaś mogą być stosowane równolegle ${ }^{6}$.

\section{Strategie w ramach tworzenia części historycznej uzasadnienia}

Część historyczna uzasadnienia formułowana jest (a przynajmniej być powinna) przede wszystkim pod kątem prawnej części uzasadnienia ${ }^{7}$. Poszczególne jej elementy są wtedy selekcjonowane ze względu na to, jaki kształt przyjmie wypowiedź zawarta właśnie w części prawnej. Część historyczna staje się więc partykularnym instrumentem dialogu sądu z adresatami jego komunikatu - wykazując (nieoczywisty na pierwszy rzut oka) dość znaczny potencjał retoryczny.

${ }^{6}$ Odmiennie o strategiach (na gruncie innego porządku prawnego) wypowiada się B. M. Atkins, Decision-making rules and judicial strategy on the United States courts of appeals, „The Western Political Quarterly” 1972, nr 4, s. 626 i n. Por. także M. A. Perino, Law, ideology, and strategy in judicial decison making: evidence from securities fraud actions, „Journal of Empirical Legal Studies” 2006, nr 3, s. 505 i n., gdzie autor wskazał na różne modele decydowania i uzasadniania: „legal model” - decyzja i uzasadnienie oparte na prawie, ,attitudinal model” - na własnych preferencjach co do wartości, poglądach politycznych oraz ,strategic model" - ukierunkowany na osiagnięcie celu. Por. także M. Bergara et al., Modeling Supreme Court strategic decision making: the congressional constraint, „Legislative Studies Quarterly” 2003, nr 2, s. 247 i n.; P. T. Spiller et al., Strategic judicial decision making, NBER Working Paper No. 13321, http://www.nber.org/papers/w13321 [dostęp: 3.03.2017]. O modelach orzekania w sposób zbliżony do zaprezentowanych strategii uzasadniania zob. P. Weiler, Two models of judicial decision-making, „Canadian Bar Review” 1968, nr 3, s. 408. Por. także ciekawe uwagi, choć w odniesieniu do innego rodzaju decyzji, O. Bachelet, Le Conseil constitutionnel valide la motivation elliptique des verdicts d'assises, Lettre „Actualités Droits-Libertés” du CREDOF, 4 kwietnia 2011 r. Odmiennie o strategiach T. R. van Geel, Understanding Supreme Court Opinions, Harlow 2007, s. 117 i n.

7 Także w sytuacjach, w których orzeczenie ma charakter formalny (jak np. przy cofnięciu skargi kasacyjnej) - można poruszyć wówczas jedynie kwestie proceduralne, nie zaś np. przytoczyć zarzuty podniesione przez stronę, gdyż w takiej sytuacji nie mają one najczęściej znaczenia dla rozstrzygnięcia. Selekcjonuje się w ten sposób treść części historycznej pod kątem tego rozstrzygnięcia. Zob. postanowienia NSA: z 8 maja 2013 r., II FSK 1840/11; z 9 maja 2013 r., II OSK 347/13; z 9 maja 2013 r., II GSK 376/12; z 27 marca 2013 r., II FSK 755/13; z 21 maja 2013 r., II OZ 384/13 (bezprzedmiotowość wstrzymania wykonania zaskarżonej decyzji ze względu na wcześniejsze wydanie wyroku w sprawie). 


\subsection{Strategia drobiazgowego przytaczania elementów części historycznej}

Jedna ze strategii w tym zakresie jest drobiazgowe przytaczanie elementów właściwych dla części historycznej - relacjonowanie wypowiedzi stron, zdarzeń w sprawie, zarzutów środka zaskarżenia, całych pism procesowych czy innych dokumentów włączonych do akt sprawy (składających się na stan faktyczny oraz dodatkowe tło historyczne sprawy). Niekiedy przytaczane sa dokładnie nawet te elementy części historycznej, które nie sa ściśle związane z rozstrzyganym problemem prawnym czy nie odzwierciedlają hipotezy normy prawnej mającej w sprawie zastosowanie.

Takie przeciążenie części historycznej służyć ma zasłonieniu się przez sąd przed zarzutem wadliwego ustalenia stanu faktycznego sprawy i w konsekwencji uchyleniem orzeczenia albo jego negatywna ocena poza kontrola instancyjna. Z perspektywy sądu oceniającego rozstrzygnięcie może jednak budzić poważne wątpliwości co do tego, czy sąd pierwszej instancji zrozumiał sedno problemu sprawy. Może być to jednak zrozumiałe, jeżeli weźmie się pod uwagę to, że podstawowym zadaniem sądu powszechnego orzekającego w pierwszej instancji jest ustalenie stanu faktycznego sprawy ${ }^{8}$.

Drugim powodem stosowania tej strategii jest stworzenie wrażenia, że skoro wszystkie te informacje znalazły się w części historycznej uzasadnienia, to zostały dokładnie przez sąd ustalone, ocenione i wzięte pod uwagę przy wydawaniu rozstrzygnięcia. Sprzyja to występowaniu zjawiska, które można określić jako „legitymizację przez pozory” - operowaniu treścią uzasadnienia w sposób mający stworzyć u adresata wrażenie wyczerpującej i pogłębionej refleksji. W takim ujęciu strategia ta jest właściwa nie tylko dla sądów powszechnych pierwszej instancji, lecz także dla innych sądów, których orzeczenia podlegaja kontroli - instancyjnej czy poza tokiem instancji oraz kontroli nieformalnej (m.in. przez strony postępowania czy inne podmioty).

Szczególna postacia tej strategii jest przytoczenie zarzutów środka zaskarżenia - często bez syntezy czy parafrazy (in extenso ${ }^{9}$, a czasami nawet in crudo ${ }^{10}$. Celem zastosowania tego zabiegu jest $\mathrm{w}$ założeniu pokazanie stronie, że jej wątpliwości zostały potraktowane poważnie oraz zbadane drobiazgowo i wnikliwie (zwłaszcza wówczas, gdy sąd związany jest granicami zaskarżenia). Służy to także zademonstrowaniu, że sąd zrozumiał zarzuty sformułowane przez stronę. Niekiedy jednak, paradoksalnie, może to budzić wrażenie powierzchowności. Kluczowe znacznie ma jednak w tym wypadku sposób od-

${ }^{8}$ F. Błahuta, Uzasadnianie orzeczenia pierwszej instancji w sprawie cywilnej, „Biuletyn Ministerstwa Sprawiedliwości” 1955, nr 4; idem, Uzasadnienie orzeczenia pierwszej instancji w sprawie cywilnej (wskazówki praktyczne), „Biuletyn Ministerstwa Sprawiedliwości” 1955, nr 4.

${ }^{9}$ Nieznacznie przetworzone zarzuty nie sa rzadkościa. Por. wyroki NSA: z 22 marca 2013 r., II OSK 2259/11; z 18 września 2012 r., II OSK 1393/12; z 7 marca 2013 r., I GSK 1258/11.

${ }^{10}$ Powoływanie zarzutów właściwie nieprzetworzonych możliwe jest do zaobserwowania po analizie stylu pisania, sposobu powoływania aktów prawnych oraz wskazywania stron postępowania (np. stosowania wielkich i małych liter w równych fragmentach stanu faktycznego). M. Domagalski, Kopiuj/wklej w wyroku, „Rzeczpospolita” z 20 grudnia 2011 r. 
niesienia się do nich w części prawnej uzasadnienia - to on ostatecznie decyduje bowiem o wartości argumentacyjnej wywodu.

Rozbudowanie części historycznej może wskazywać na niewielki wkład własny sąu w jej zredagowanie i poprzestanie na skopiowaniu treści akt sprawy, zwłaszcza pism procesowych. W sytuacji hipertrofii części historycznej część prawna często nie jest w stanie dorównać jej objętościowo, co wywołuje efekt nieco karykaturalny ${ }^{11}$.

\subsection{Strategia formułowania części historycznej w sposób skondensowany}

Inną strategią przyjmowaną w ramach części historycznej jest formułowanie poszczególnych jej elementów w sposób bardziej skondensowany. Strategia ta może przybierać postać albo wyboru najistotniejszych treści z całego materiału sprawy (np. przytaczania wybranych pism procesowych, pomijania tych, które nie mają dla rozstrzygnięcia znaczenia), albo syntezy całości zdarzeń w sprawie. Ma ona zastosowanie zwłaszcza wtedy, gdy uzasadnienie sporządzane jest do orzeczenia sądu wyższej instancji - które nie będzie już raczej podlegało kontroli. Nie zachodzi więc obawa przed negatywną ocena pominięcia elementu stanu faktycznego istotnego z perspektywy rozstrzygnięcia.

Szczegółowe informowanie o okolicznościach sprawy i dotychczasowym przebiegu postępowania nie jest $\mathrm{w}$ tym wypadku konieczne także $\mathrm{z}$ tego powodu, że strony postępowania, do których najczęściej jest kierowane uzasadnienie, bądź znają doskonale te okoliczności, bądź są zainteresowane nimi często jedynie w minimalnym zakresie, koniecznym do zrozumienia części prawnej.

Strategia ta znajduje zastosowanie zwłaszcza do uzasadnień orzeczeń sądów wyższych instancji także z tego powodu, że na tym etapie rozpoznawania sprawy wyraźnie widoczny jest problem prawny, który musi zostać rozstrzygnięty. Sądy niższej instancji ze względów pragmatycznych często odnoszą się do wszelkich aspektów sprawy. Niekiedy dopiero na kolejnym szczeblu jej rozpoznania, zwłaszcza po rozpatrzeniu zarzutów sformułowanych w środku zaskarżenia, które często ukierunkowują rozstrzygnięcie, można dostrzec to, co jest w sprawie najistotniejsze. Wówczas część historyczna może skupić się na tych elementach, które korespondują z konkretnym rozstrzygnięciem, pomijając lub skrótowo omawiajac pozostałe. Jest to szczególnie widoczne w uzasadnieniach sądów administracyjnych, a zwłaszcza NSA, który jest związany granicami zarzutów sformułowanych w skardze kasacyjnej. Wówczas sąd odnosi się w części prawnej przede wszystkim do tych zarzutów, a w konsekwencji na tym koncentruje się skorelowane z zawartymi tam rozważaniami sądu przedstawienie tła faktograficznego w części historycznej uzasadnienia.

Posługiwanie się tą strategią przez sądy ulokowane wyżej w hierarchii sądownictwa nie jest jednak reguła. Do bardziej drobiazgowego formułowania części historycznej uzasadnień orzeczeń sądów wyższej instancji dochodzić może bowiem wówczas, gdy uzasadnienie sporządzane jest do orzeczenia ja-

11 Zob. szerzej na temat hipertrofii części historycznej uzasadnienia: M. Grochowski, Uzasadnienie orzeczenia sqdu drugiej instancji $i$ jego deficyty (studium przypadku), „Państwo i Prawo” 2014, z. 2. 
kiegokolwiek sądu, ale cechującego się „precedensową" naturą lub z innych względów mogącego stanowić przedmiot szerszej dyskusji (np. uchwały). Uzasadnienia orzeczeń sądów najwyższej instancji, zwłaszcza rozstrzygających sprawy o charakterze precedensowym, kierowane są najczęściej także do szerszego grona odbiorców - środowiska prawniczego i społeczeństwa. Wynika to z pozycji orzeczeń tych sądów jako ulokowanych wysoko w strukturze sądownictwa. Stąd często potrzeba szerszego zarysowania tła faktograficznego orzeczenia, które wraz z częścią prawną daje pełny obraz rozstrzygnięcia.

\section{Strategie w ramach tworzenia części prawnej uzasadnienia}

\subsection{Strategia dyskursywna}

W przypadku części prawnej uzasadnienia zaobserwować można dwie główne strategie jej tworzenia. Pierwszą z tych strategii określić można jako „dyskursywną" (,reakcyjną" czy referencyjna). Polega ona na potwierdzaniu (aprobowaniu) lub kwestionowaniu twierdzeń i argumentów podnoszonych przez strony lub innych treści akt sprawy poprzez odnoszenie się do nich w sposób sukcesywny - traktujący każdy z nich jako osobny problem wymagający omówienia. Strategia ta pozostaje więc silnie ukierunkowana na komentowanie przez formułowanie argumentów. Co oczywiste, jest ona najsilniej reprezentowana $\mathrm{w}$ tych fragmentach uzasadnienia, których głównym adresatem są strony postępowania. Warunkiem pełnej dyskursywności jest wówczas przytoczenie wypowiedzi strony (w szczególności formułowanych przez nią zarzutów) w części historycznej i odniesienie się do każdego z nich w rozważaniach prawnych ${ }^{12}$. W skrajnej postaci autor uzasadnienia odpowiada wówczas na każdy z przytoczonych argumentów, nawet najbardziej absurdalny czy nierzeczowy, wskazując własny kontrargument o charakterze stricte merytorycznym ${ }^{13}$. W ten sposób sąd daje przede wszystkim wyraz poważnemu potraktowaniu każdej rozpoznawanej sprawy oraz szacunkowi dla obywatela - wynikającemu z pozycji sądu w państwie demokratycznym.

Strategia dyskursywna stosowana jest także wówczas, gdy sąd ma świadomość, że strona czy jej pełnomocnik szczegółowo zapoznają się z treścią rozstrzygnięcia i moga formułować na tej podstawie wnioski odwoławcze zmierzajace do jego weryfikacji. Podobnie sytuacja przedstawia się w przypadku sądu wyższego szczebla uchylającego wadliwe orzeczenie, który wprost ocenia rozumowanie zawarte w kontrolowanym rozstrzygnięciu. Mając świadomość, że orzeczenie (a właściwie: motywy przytoczone na jego poparcie) może być przedmiotem kontroli innego organu, sąd będzie konstruował uzasadnienie w taki sposób, aby jak najpełniej przedstawić i wyjaśnić argumenty, które zaważyły na kształcie wydanego rozstrzygnięcia.

12 Por. np. wyrok NSA z 5 kwietnia 2013 r., I FSK 840/12; wyrok SA w Warszawie z 18 stycznia 2017 r., II AKa 466/16; wyrok SA w Warszawie z 30 grudnia 2016 r., II AKa 190/16; wyrok SR z 30 czerwca 2004 r., VIII K 495/03; wyrok SA w Łodzi z 9 kwietnia 2015 r., I ACa 1502/14.

13 Por. postanowienie NSA z 15 maja 2013 r., II OZ 359/13. 


\subsection{Strategia monologowa}

Drugą strategię nazwać można „monologowa” ${ }^{14}$ - przybiera ona bowiem postać pisemnego wywodu na temat danego problemu prawnego, który pojawił się w sprawie (czy instytucji prawnej majacej w niej zastosowanie) lub jest własna propozycją rozwiązania występujacych w niej zagadnień, lecz, co kluczowe dla tej strategii, bez odnoszenia się do twierdzeń formułowanych przez strony. Wypowiedź sądu tworzona w ten sposób nie stanowi dyskursu z twierdzeniami, zarzutami i argumentami podnoszonymi przez strony czy też materiałem sprawy, lecz jest monologiem przedstawiającym najczęśsciej jedynie trafny, w ocenie sądu, punkt widzenia. Przypomina ona niekiedy rozwiązanie abstrakcyjnego kazusu, w którym sąd przedstawia swój pogląd $\mathrm{w}$ danej sprawie, ewentualnie z mniejszą lub większą dozą odniesień do realiów danego przypadku. Ma to w skrajnej postaci miejsce w sytuacji, w której autor uzasadnienia nie może - ze względu na zawiłość lub nierzeczowość sformułowania wypowiedzi podmiotów występujących w sprawie - odnieść się do każdego twierdzenia czy okoliczności sprawy z osobna lub gdy znalezienie i przytoczenie kontrargumentów wydaje się czynnością zbyt trudną (w szczególności w sytuacji orzekania w pewnym zakresie na podstawie wewnętrznego poczucia słuszności w kulturze prawnej opartej na stosowaniu prawa stanowionego). Wówczas strategia ta prowadzi do stworzenia rozbudowanej wypowiedzi z wyraźnym zaznaczeniem akcentów konstytucyjnych, europejskich czy międzynarodowych (zarówno w zakresie prawa jak i orzecznictwa).

Korzystanie z tej strategii może być motywowane rolą i pozycją sąów wyższych instancji, które to sądy spośród wszystkich najczęściej formułują uzasadnienia w ten właśnie sposób. Nie muszą one obawiać się uchylenia orzeczenia wskutek nieodniesienia się do jakichś twierdzeń. Obok jej oczywistych wad, strategia ta służy też zademonstrowaniu, w założeniu, silniejszej kompetencji w zakresie autonomicznego decydowania w sprawach. Może także realizować rolę tych sądów jako formułujących również myśli bardziej uniwersalnej natury. Użycie strategii monologowej wynikać może też z powodów czysto pragmatycznych - uzasadnienie pisane w taki właśnie sposób jest łatwiejsze w przygotowaniu.

\section{TECHNIKI UZASADNIANIA}

Strategie należą do bardziej ogólnych założeń budowania wywodu w wypowiedzi, jaką jest uzasadnienie. W ramach strategii występują także pewne techniki, akcentujące poszczególne aspekty uzasadniania w obu częściach tej wypowiedzi. Sa one bardziej skonkretyzowanymi zabiegami, które jednak nie zmieniaja zasadniczej konstrukcji narracji określonej przez strategie. Określone techniki moga występować w ramach tych konkretnych strategii, które nie wykluczaja całkowicie ich zastosowania. Dotyczą najczęściej sposobu wprowadzania argu-

${ }^{14}$ Nie należy mylić strategii monologowej i dyskursywnej ze stylem dyskursywnym i magisterialnym (monologowym), wyróżnionym w opracowaniu L. Morawskiego i M. Zirk-Sadowskiego, Precedent in Poland, w: N. MacCormick, R. Summers (eds.), Interpreting Precedents. A Comparative Study, Dartmouth 1997, s. 225-226. 
mentacji i wynikaja wyraźnie z pragmatyki orzekania. W przeciwieństwie do strategii, których jednoczesne użycie we właściwej im części uzasadnienia nie jest w zasadzie możliwe, techniki są środkami, które mogą być stosowane równolegle, zarówno w całym uzasadnieniu, jak i jego poszczególnych częściach.

Wymienione techniki są tylko przykładami wielu możliwych technik uzasadniania, z cała pewnością nie wszystkie z nich zostały dotychczas zidentyfikowane. Techniki dotyczą bowiem sięgania po wiele narzędzi wykorzystywanych przy tworzeniu wypowiedzi tego typu (np. używania określonych sformułowań czy konstrukcji językowych), które mają charakter szczegółowy.

Omówionej niżej techniki wybrane zostały jako najbardziej interesujace prawie wszystkie z nich wydaja się bowiem atypowe. Z przedstawionych technik uzasadniania pozornie wynikać może dosyć negatywny obraz sądu jako podmiotu dążącego do moderowania swojej wypowiedzi w innych celach, niż powszechnie przyjęte i ujawnione w uzasadnieniu. Nie odzwierciedla to jednak całego spektrum technik, jakimi posługują się sądy w ramach przyznanej im swobody kreowania wypowiedzi zawartej w uzasadnieniu. W każdym jednak przypadku są one instrumentem służącym do osiagnięcia konkretnego efektu przez autora uzasadnienia.

\section{Technika ornamentacyjna}

Jedna $\mathrm{z}$ istotnych technik jest ornamentacyjne powoływanie wypowiedzi doktryny i orzecznictwa ${ }^{15}$. Technika ta polega na przytaczaniu $\mathrm{w}$ uzasadnieniu stanowisk przedstawicieli nauki prawa i judykatury w celu wsparcia własnego poglądu sądu w sprawie - jednakże bez związku z rzeczywistym wykorzystaniem tych wypowiedzi we własnym rozumowaniu sądu. Przybiera ona zazwyczaj postać albo cytowania odpowiednich tez czy passusów tych wypowiedzi, albo powoływania ich poprzez wskazanie na sygnaturę czy zapis bibliograficzny ${ }^{16}$. Technika ta ma za zadanie stworzenie wrażenia, że w sprawie wystapił istotny problem prawny, wymagający szerokiego zbadania. Świadczyć ma o znaczącym nakładzie pracy, jaki wykonał sąd i sam autor uzasadnienia. Technika ta stosowana jest także wtedy, gdy samo rozstrzygnięcie nie znajduje całkowicie stabilnego oparcia w prawie pozytywnym (jego podstawa jest inna - np. względy słuszności). Przytoczenie wypowiedzi innych podmiotów ma wtedy nie tyle realne znaczenie dla podjętej decyzji, wzmacniając rzeczywistą motywację stojąca za rozstrzygnięciem poprzez powołanie się w uzasadnieniu np. na wartości chronione konstytucyjnie, ile legitymizuje wywód zawarty w uzasadnieniu ${ }^{17}$.

${ }^{15}$ Ch. A. Newland, Innovation in judicial technique: the Brandeis opinion, Materiały z seminarium Idaho State College z 9 lutego 1960 r., s. 5.

${ }^{16}$ Cytowanie orzeczeń podnosi z drugiej strony rangę orzeczeń cytowanych - zob. F. B. Cross et al., Citations in the U.S. Supreme Court: an empirical study of their use and significance, „University of Illinois Law Review" 2010, nr 2(18), s. 489 i n.

${ }_{17}$ Por. szerzej: I. Rzucidło-Grochowska, Argumentacja konstytucyjna w uzasadnieniach orzeczeń sqdów administracyjnych. Znaczenie i typologia, w: J. Sułkowski et al. (red.), Kontrola konstytucyjności prawa a stosowanie prawa w orzecznictwie NSA, SN i TK, publikacja w przygotowaniu. O potrzebie stosowania chwytów retorycznych, gdy brak silnych argumentów prawnych, zob. R. Moss, Rhetorical stratagems in judicial opinions, „Scribes Journal of Legal Writing” 1991, nr 2, s. 104. 


\section{Technika ,unikania oczywistości”}

Jedną z technik, która właściwa jest raczej tylko strategii monologowej, jest tzw. technika unikania oczywistości. Sprowadza się ona do przytoczenia zasady clara non sunt interpretanda ${ }^{18}$ (wprost, w parafrazie albo w sposób dorozumiany) jako sposobu unikania przedstawiania własnej argumentacji (na poziomie retorycznym w uzasadnieniu, nie zawsze zaś jako element rozumowania sądu). Tak skonstruowana część prawna pozbawiona jest swojej istoty i można ją określić jako „uzasadnienie bez uzasadnienia”. Z perspektywy argumentacyjnej stwierdzenie, że dana regulacja jest jasna, ucina dalsza dyskusję, pozwalając sądowi na odstapienie od uzasadniania czegoś rzekomo oczywistego $^{19}$. Jest ona jednak wykorzystywana najczęściej tylko z pozornym przekonaniem o jasności regulacji, w celu zamaskowania rzeczywistej intencji - najczęściej uniknięcia uzasadnienia kwestii trudnej czy skomplikowanej20. Posługiwanie się tym elementem klaryfikacyjnej koncepcji wykładni prawa może przybierać formę obok „oczywistości wprost”, o której już powiedziano, także postać „oczywistości dorozumianej”. Dorozumiane posługiwanie się tym elementem koncepcji klaryfikacyjnej polega na przemilczeniu w uzasadnieniu określonych treści (np. rozumowań, a także argumentacji na ich rzecz), gdy autor uzasadnienia uważa je za oczywiste (lub chce, aby były za takie uważane) i w sposób milczacy daje temu wyraz, pomijając je w swoim wywodzie ${ }^{21}$.

Zagadnieniem związanym z tą technika jest kwestia unikania ujmowania w uzasadnieniu subsumpcji. Jest to wyraźny obszar deficytu w części prawnej wielu uzasadnień. Najczęściej nie jest to zabieg stosowany intencjonalnie, jest raczej wyrazem braku przykładania wagi do skrupulatnego odzwierciedlenia w uzasadnieniu kwestii z pozoru oczywistej. Może być też spowodowany brakiem uzmysłowienia sobie przez autora uzasadnienia tego, że ten element procesu stosowania prawa, zachodzący niekiedy niemalże automatycznie, należałoby przekazać w uzasadnieniu.

18 Szerzej: T. Grzybowski, Spory wokót reguty clara non sunt interpretanda, „Państwo i Prawo” 2012, z. 9, passim; Z. Tobor, W poszukiwaniu intencji prawodawcy, Warszawa 2013, s. 24 i n.; M. Zirk-Sadowski, Trzy ujęcia zasady clara non sunt interpretanda jako zakazu inicjowania interpretacji, w: System prawa administracyjnego, red. R. Hauser, Z. Niewiadomski, A. Wróbel, t. 4: Wyktadnia $w$ prawie administracyjnym, red. L. Leszczyński, B. Wojciechowski, M. Zirk-Sadowski, Warszawa 2012, s. 156-159.

${ }_{19}$ Sąd stosujący taki zabieg popada w sprzeczność, twierdząc, że przepisy sąjasne i nie należy dokonywać ich interpretacji, gdyż już samo takie stwierdzenie jest dokonaniem wykładni. Nie można bowiem w sposób subiektywny przypisywać niczemu właściwości obiektywnej w postaci jasności.

20 Jest to szczególnie widoczne w przypadku postanowień wydawanych na posiedzeniu niejawnym w sprawach - co do zasady - mniejszej wagi, adresowanych najczęściej do bardzo wąskiego kręgu adresatów - głównie stron postępowania. Takim uzasadnieniom niejednokrotnie brakuje odzwierciedlenia fazy subsumpcyjnej, co oznacza, że przekaz sprowadza się tylko do autorytatywnych twierdzeń. Podobnie sytuacja przedstawia się przy wypełnianiu treścią klauzul generalnych. Posługiwanie się - wprost lub w sposób dorozumiany - kryterium jasności i oczywistości regulacji prawnych jako ucieczka od wskazania motywów podjętej przez siebie decyzji zdecydowanie obniża prestiż sądu w oczach adresatów uzasadnienia.

21 P. M. Wald, The rhetoric of results and the results of rhetoric: judicial writings, "The University of Chicago Law Review” 62(4), 1995, s. 1373. 


\section{Technika „legitymizacji przez ilość”}

Jeszcze inną technika, mającą zastosowanie do części prawnej uzasadnienia orzeczenia sądu każdego rodzaju i szczebla, jest technika, którą można określić jako „legitymizację przez ilość”. Polega ona na przytaczaniu znacznej liczby poglądów nauki prawa i orzecznictwa sądowego, podobnie jak w przypadku techniki ornamentacyjnej, lecz w przeciwieństwie do niej przywołania te wykazuja związek $\mathrm{z}$ rzeczywiście przeprowadzonym $\mathrm{w}$ sprawie rozumowaniem sądu (stały się np. argumentem interpretacyjnym w procesie decyzyjnym). Technika ta ma służyć wskazaniu, że problem w sprawie został przeanalizowany wnikliwie, z wielu stron, a tym samym zapewnić legitymizację rozstrzygnięcia. Posługiwanie się dorobkiem doktryny i judykatury, zwłaszcza w znacznym natężeniu, jest też wyrazem poszukiwania zewnętrznych źródeł odniesienia (zewnętrznych autorytetów) w celu silniejszej akceptacji orzeczenia ${ }^{22}$.

Technika ta ma zarówno wyraźne zalety, jak i wady. Problem z jej stosowaniem i postrzeganiem $\mathrm{w}$ niektórych sytuacjach jako niewłaściwej polega na tym, że w wielu przypadkach przywoływanie licznych poglądów nauki i orzecznictwa stanowi nie tylko odzwierciedlenie pracy wykonanej nad sprawa, ale w skrajnych przypadkach głównie pokazanie erudycji. Skutkuje to nadmiernym rozbudowaniem części prawnej uzasadnienia, zwykle bez realnej potrzeby w tym zakresie.

Podobnie snucie rozległych opowieści o istocie, rodowodzie i problemach z korzystaniem z konkretnej instytucji prawnej, mającej w sprawie zastosowanie, pomimo tego, że nie jest to sporne w orzecznictwie czy nauce, bywa zwyczajnie zbędne z perspektywy rozstrzygnięcia, nawet jeżeli był to element rozumowania sądu. Posługiwanie się tą techniką może bowiem rozproszyć i odciagnąc uwagę od głównego konkretnego problemu rozstrzyganego w sprawie, powodować niewłaściwe rozłożenie akcentów w uzasadnieniu (np. marginalizować wskazanie subsumpcji), a tym samym utrudniać zapoznanie się $\mathrm{z}$ orzeczeniem.

Korzystanie $\mathrm{z}$ tej techniki może też wielokrotnie paradoksalnie szkodzić odbiorowi uzasadnienia z tego powodu, że pokazuje duży wysiłek włożony w podjęcie decyzji i jej uzasadnienie, często jednak niewspółmierny do ostatecznego efektu (np. rozstrzygnięcia w sprawie wpadkowej o typowym problemie powstającym $\mathrm{w}$ tym zakresie).

Jednakże w niektórych sytuacjach zaprezentowanie tego, że wielokrotnie, zarówno w nauce prawa, jak i orzecznictwie, zajęto tożsame stanowisko w określonym zakresie służyć może wyraźnemu potwierdzeniu zdania sądu, a przez to wzmocnieniu własnego poglądu wyrażonego w orzeczeniu. Może okazać się to istotne zwłaszcza w sytuacjach, w których sąd rozstrzyga sprawę trudną lub mającą walor nowości. Wówczas może wesprzeć się częściowo (co do

${ }^{22} \mathrm{~W}$ przypadku odwołań do orzecznictwa można mówić o poszukiwaniu autorytetu zewnętrzno-wewnętrznego - ulokowanego wciąż w ramach wypowiedzi judykatury, lecz spoza konkretnego procesu stosowania prawa $\mathrm{w}$ danej sprawie. 
jakiejś części rozumowania) wypracowanym już poglądem, w pozostałej części, co do której dotychczas sądy czy nauka prawa nie miały okazji się wypowiedzieć, działając zupełnie autorsko. W takiej sytuacji technika ta pozwala na ułatwienie uzyskania akceptacji dla orzeczenia - nieformułowanego całkowicie autonomicznie, lecz korespondującego $\mathrm{z}$ dotychczasowym dorobkiem nauki i judykatury, w przynajmniej pewnym zakresie.

Inna zaletą tej techniki jest to, że uzasadnienie tworzone z jej wykorzystaniem może być traktowane jako poważne zajęcie się sprawa, nawet w sytuacji typowej, w której często za usprawiedliwione można by uznać wykorzystanie jako wzór innych orzeczeń.

Trzeba jednak mieć na uwadze to, że pomiędzy przytaczaniem dorobku doktryny i judykatury w tych celach, które niewątpliwie służą sądownictwu, a jego nieuzasadnionym nadmiernym powoływaniem, które judykaturze szkodzi, przebiega bardzo cienka granica.

\section{Technika „przemilczenia”}

Inną techniką stosowaną w ramach części historycznej, ale mająca bezpośrednie przełożenie na część prawną jest technika „przemilczenia”. Może ona mieć wiele postaci. Najczęściej sprowadza się ona do tego, że autor uzasadnienia pomija pewne elementy części historycznej (zwłaszcza twierdzenia czy zarzuty stron), aby nie musieć następnie odnosić się do nich w części prawnej. Może też dotyczyć kwestii problematycznych, do których trudno się ustosunkować, a nie mają one znaczenia dla sprawy. Dzieje się tak najczęściej wtedy, gdy orzeczenie i tak przybrałoby konkretny kształt bez względu na odniesienie się przez sąd do danej kwestii (np. wówczas gdy środek odwoławczy i tak podlegałby oddaleniu jako niezasadny, a jeden z argumentów skarżącego - choć nieprzesądzający - wymagałby jednak złożonych zabiegów argumentacyjnych). Dotyczy to także absurdalnych twierdzeń strony, dalekich od meritum sprawy, np. koncentrujących się na przekazaniu sądowi własnych odczuć i opinii (daniu wyrazu poczuciu krzywdy, opisowi osobistych relacji z druga stroną postępowania, odwołań mających wzbudzić litość itp.). Odnoszenie się przez sąd do tego typu twierdzeń, zwłaszcza obszerne i dokonane nieumiejętnie, mogłoby narażać uzasadnienie na śmiesznośćc ${ }^{23}$. Traktowanie tego typu wypowiedzi jako równoprawnych twierdzeń strony pozornie tylko stwarzałoby wrażenie poważnego zajęcia się sprawą. Wydaje się, że paradoksalnie tylko w nielicznych przypadkach próby merytorycznego odnoszenia się do twierdzeń pozamerytorycznych budowały pozytywny odbiór wymiaru sprawiedliwości ${ }^{24}$.

\footnotetext{
${ }^{23}$ Akceptowalne wydają się twierdzenia typu ,jakkolwiek sąd rozumie trudną sytuację strony, to jednak..."

${ }^{24} \mathrm{~W}$ pewnym sensie przykładem może być np. krążące w środowisku sądowym orzeczenie, w uzasadnieniu którego sędzia w drobiazgowy i naukowy sposób wykazywał brak osobistych praw autorskich powoda do Pisma Świętego (Biblii).
} 


\section{Technika ukierunkowanego eksponowania treści w uzasadnieniu}

Jeszcze inną technika jest ta, która została w literaturze określona jako manipulowanie faktami (koloryzowanie) ${ }^{25}$. W istocie jest najczęściej eksponowaniem treści w uzasadnieniu w sposób ukierunkowany. Polega ona na akcentowaniu w uzasadnieniu, zwłaszcza w jego części historycznej, tych elementów, które przemawiają na korzyść rozstrzygnięcia wybranego przez sąd, pomijaniu zaś przeciwnych. Uzasadnienia tworzone jako dowód z góry ustalonej tezy eksponują tylko racje przemawiające za obranym poglądem, maskując lub wręcz przemilczając argumenty przeciwne lub nie przemawiające jednoznacznie na rzecz jednego ze stanowisk. Dotyczy to na przykład eksponowania faktów świadczących o winie skazanego czy o odpowiedzialności sprawcy szkody, może sprowadzać się także do używania określeń nacechowanych w sposób, który ma wywołać pożądane przez autora uzasadnienia wrażenie (np. brutalności sprawcy czy braku winy). Ma to budować w odbiorcy przekonanie o trafności wydanego rozstrzygnięcia, oparte jednak nie tyle na merytorycznej wartości argumentów, ile na wytworzeniu u jego odbiorcy pewnego wrażenia, postawy czy wywołaniu emocji.

\section{Technika „uzasadnień kontrolujących”}

Jeszcze inna technika ma zastosowanie do uzasadniania orzeczeń sądów wyższych instancji lub sądów administracyjnych (a więc tam, gdzie wypowiedź określonych podmiotów podlega kontroli przez sądowe organy nadrzędne). Polega ona na konstruowaniu części prawnej w dwojaki sposób, zależnie od preferencji autora uzasadnienia i okoliczności towarzyszacych rozstrzyganiu sprawy. Zgodnie z pierwszym sposobem, który jest właściwy dla strategii dyskursywnej, autor uzasadnienia odnosi się do każdego argumentu, każdego twierdzenia zawartego w piśmie procesowym strony z osobna, aby następnie stwierdzić, że ich uwzględnienie lub brak uwzględnienia skutkuje wydaniem przez sąd konkretnego rozstrzygnięcia. Odnoszenie się do tych twierdzeń stron zawiera w sobie nie tylko wypowiedzi czysto referencyjne, ale także wskazywać może - dla pokazania kontrastu - prawidłowy sposób rozumowania w sprawie. Drugi sposób, z pozoru zbliżony do strategii monologowej, lecz mający zastosowanie głównie w jej dyskursywnym odpowiedniku, polega natomiast na tym, że oceniając zasadność środka zaskarżenia czy po prostu twierdzeń strony lub odnosząc się do akt sprawy, autor uzasadnienia może najpierw zaprezentować wzorcowy sposób rozstrzygnięcia sprawy (ewentualnie oceniając w konsekwencji pod tym kątem kontrolowane orzeczenie), a następnie odnieść do niego twierdzenia stron zawarte w pismach procesowych, odpowiadajac na kolejne zawarte w nich argumenty. W tym drugim przypadku widać wyraźniej, że z procesowego (ale także teoretycznego) punktu widzenia wystarczające byłoby samo przedstawienie wersji idealnego rozwiązania spra-

${ }^{25}$ R. Moss, op. cit., s. 106. Zob. także szerzej o manipulowaniu w uzasadnieniu: K. Schmidt, Uzasadnienia sqdowe jako impuls zwrotny dla teorii, w: M. Sadowski, P. Szymaniec (red.), Prace $z$ historii oraz teorii prawa $i$ administracji publicznej, Acta Erasmiana IV, Wrocław 2012, s. 11 i n. 
wy, a odnoszenie się do twierdzeń stron stanowi dodatkową wartość uzasadnienia. Technika ta ma na celu pokazanie indywidualnego podejścia do sprawy i jej uzasadnienia, nie zaś potraktowania jej szablonowo. Ponadto odpowiadanie na każde twierdzenie strony (zwłaszcza przeciwne do kierunku orzeczenia) może stworzyć wrażenie, że rozstrzygnięcie jest w pełni przemyślane i nie było możliwości podjęcia go w innym kształcie - sąd bowiem jest w stanie merytorycznie odpowiedzieć na każdy kontrargument.

Technika ta jest stosowana czasem także w przypadku orzeczeń o charakterze precedensowym lub rozstrzygajacych skomplikowany problem prawny. Najpierw następuje wówczas zarysowanie ogólnego tła, wprowadzenie do ustalonego przez sędziego sposobu rozumienia i stosowania danej instytucji prawnej, a następnie konkretyzacja z elementami odniesienia się do podnoszonych zarzutów.

\section{PODSUMOWANIE}

Wyróżnienie i stosowanie strategii, a w szczególności technik formułowania uzasadnienia ujawnia rozdźwięk pomiędzy odkryciem a uzasadnieniem ${ }^{26}$. Techniki, strategie i style pokazuja, że nawet jeżeli autor uzasadnienia jest tożsamy z podejmującym decyzję, to sposób uzasadniania w celu osiagnięcia decyzji (na poziomie rozumowania) może być inny niż na poziomie następczego uzasadnienia po wydaniu tej decyzji. Można bowiem w inny sposób uzasadniać w toku stosowania prawa, a następnie tworzyć odmienne uzasadnienie pisemne, posługując się konkretnymi strategiami i technikami niezależnie od rzeczywistego rozumowania, w celu wywołania określonego rezultatu, zwłaszcza retorycznego (czy komunikacyjnego). Różnorodność strategii i technik pokazuje, że można w różny sposób prowadzić narrację na temat tej samej decyzji, nawet jeżeli czegoś nie chce się ujawnić (stosuje się wówczas odpowiednie zabiegi). Jeżeli mamy do czynienia z sytuacją typowa, w której sąd chce przekazać rzeczywiste motywy orzeczenia, także można zrobić to wielorako, posługując się wieloma strategiami i technikami - to one bowiem służą do wyrażenia sposobu, w jaki treść ta ma zostać przekazana.

Zupełnie osobną kategorią uzasadnień są natomiast te, które w ogóle nie mieszczą się w przedstawionych powyżej schematach - uzasadnienia bez strategii, w których trudno odgadnąć intencję autora. Potencjalni adresaci sa w tym przypadku niemalże całkowicie zignorowani, a stworzenie uzasadnienia traktowane jest jedynie jako sprostanie wymogom proceduralnym nałożonym przez prawo procesowe.

dr Iwona Rzucidto-Grochowska

Koordynator projektu „Sadowe stosowanie prawa”

w Instytucie Nauk Prawnych PAN, Warszawa

rzucidloiwona@gmail.com

${ }^{26}$ Autorzy uzasadnienia nie zawsze podają w nim rzeczywiste motywy orzeczenia - R. A. Leflar, Honest judicial opinions, „Northwestern University Law Review” 74(5), 1979, s. 721 i n. 


\title{
STRATEGIES AND TECHNIQUES USED \\ IN THE PREPARATION OF JUDICIAL OPINIONS
}

\author{
Sum mary
}

The structure of a judicial opinion is determined by specific legal provisions regulating particular kinds of proceedings. These provisions are of general character and specify only the basic elements of judicial opinions, and filling them with a content is a task for the authors. It can be done by using strategies and techniques of the preparation of judicial opinions, which are related to the result to be achieved and the tools that are used for this purpose. Different strategies in the preparation of the 'historical' part of a judicial opinion (containing factual findings) and the legal reasoning (that reflects the main judicial reasoning in the case) may be distinguished. The former category includes the strategy of referring to detailed elements of the historical part of a judicial opinion and the strategy of a condensed historical part of the opinion. The latter includes the discursive strategy and the strategy of a monologue. Among the techniques that are used by authors of judicial opinions in the frame of these strategies are: the technique of ornament, the technique of avoidance of obviousness, the technique of legitimisation by the number of utterances from the judiciary and legal scholarship, the technique of leaving things unsaid, the technique of result-oriented content exposing, or the technique of judicial opinions of courts of higher instance. 